\title{
Meningkatkan Prestasi Belajar Matematika Materi Lingkaran Dengan Metode Dienes Siswa Kelas VI Semseter I SDN Mumbang Kec. Kopang Tahun Pelajaran 2019/2020
}

\author{
Muhamin \\ SDN Mumbang Kecamatan Kopang
}

\begin{abstract}
Abstrak. Hasil pengamatan di dalam kelas saat pembelajaran Matematika berlangsung, siswa kelas VI cenderung pasif dan aktivitas belajar Matematika siswa sangatlah kurang. Untuk pelajaran Matematika nilai rata-rata yang diperoleh siswa kelas VI pada Lingkaran merupakan materi sebelum dilakukannya penelitian Nilai rata-ratanya adalah 60,46. dan persentase jumlah siswa yang mencapai standar ketuntasan belajar sebesar 54,55 \% Nilai ini sangatlah jauh dari persentase jumlah siswa yang mencapai standar ketuntasan belajar mengajar (SKBM) yang ditetapkan di SD Negeri Mumbang, yaitu sebesar 80\%. Penelitian tindakan kelas (PTK) ini dilaksanakan selama 3 bulan dengan menggunakan metode Dienes dalam upaya meningkatkan Prestasi belajar Matematika siswa kelas VI Semester I SD Negeri Mumbang Kecamatan Kopang Penelitian dilaksanakan dalam dua siklus masing-masing terdiri dari dua pertemuan melalui tahapan-tahapan sebagai berikut perencanaan, tindakan obervasi dan refleksi. Teknik pengumpulan data dilakukan melalui lembar pengamatan oleh observer untuk melihat data tentang aktivitas belajar dan mengajar, sementara data tentang hasil belajar diperoleh melalui nilai ulangan harian dan prestasi belajar siswa pada siklus 1, dan disiklus 2. Hasil yang diperoleh dari Penelitian Tindakan Kelas (PTK) melalui model metode Dienes memperlihatkan peningkatan hasil aktivitas guru pada siklus I adalah 2,88 meningkat pada siklus II menjadi 3,0 ,Prosentase ketuntasanbelajar siswa pada siklus I siswa 63,64 \% dan meningkat menjadi 90,91 \% (Sangat Baik) pada siklus II.
\end{abstract}

\section{Kata kunci : Metode Dienes, Lingkaran, Prestasi Belajar Matematika}

\section{PENDAHULUAN}

Tujuan mata pelajaran Matematika SD menurut Kurikulum Tingkat Satuan Pendidikan (KTSP) tahun 2006, adalah menumbuhkan dan mengembangkan keterampilan berhitung (menggunakan bilangan) sebagai alat dalam kehidupan sehari-hari, menumbuhkan kemampuan anak didik yang dapat dialihgunakan melalui kegiatan Matematika, mengembangkan kemampuan dasar Matematika sebagai bekal lebih lanjut, membentuk sikap yang logis, kritis, cermat, kreatif, dan disiplin.

Proses pembelajaran merupakan inti dari pendidikan di sekolah. Agar tujuan pendidikan dan pembelajaran berjalan dengan benar maka dalam belajar, motivasi siswa sangat mendukung untuk meraih keberhasilan dalam kegiatan belajar. Motivasi belajar siswa akan muncul apabila didukung oleh sistem pembelajaran yang menarik dan menyenangkan bagi peserta didik. Oleh karena itu membangkitkan motivasi siswa didalam belajar merupakan faktor yang sangat mendukung untuk keberhasilan dalam proses pembelajaran.

Sebagaimana motivasi merupakan daya/ pembangkit yang ada dalam diri sesorang yang menimbulkan kegiatan - kegiatan belajar sehingga stujuan yang ingin di kehendaki oleh siswa bisa tercapai sesuai dengan apa yang diinginkan (Saifuddin dkk,2008:40). Motivasi dibedakan menjadi dua bagian yaitu motivasi intrinsik dan motivasi ekstrinsik. Motivasi intrinsik adalah motivasi yang datang dari dalam diri siswa, sedangkan motivasi ekstrinsik adalah motivasi yang datangnya dari luar diri siswa, contohnya: motivasi yang datang dari guru. Guru dapat memberikan motivasi kepada siswa bisa dengan beberapa cara memberi angka dan berupa penghargaan.

Motivasi belajar siswa erat kaitannya dengan prestasi belajar siswa. Siswa yang termotivasi belajar maka akan lebih tertarik mengikuti proses pembelajaran sehingga 
siswa akan lebih memahami materi pembelajaran yang diajarkan. Dengan pemahaman materi pembelajaran akan memudahkan siswa menjawab soal-soal dan dapat meningkatkan prestasi siswa dalam pembelajaran.

Pembelajaran Matematika di SD seringkali mengalami masalah. Diantaranya motivasi dan prestasi belajar siswa yang rendah. Hal ini disebabkan karena penggunaan metode pembelajaran yang monoton, yaitu hanya guru saja yang aktif memberikan materi pembelajaran sementara siswa pasif dan hanya mendengarkan penjelasan guru tanpa ikut terlibat dalam pembelajaran. Selain itu, kurangnya penggunaan alat peraga dalam pembelajaran Matematika juga menjadi kendala bagi siswa dalam memahami materi pembelajaran.

Demikian pula halnya dengan siswa kelas VI SDN Mumbang Kecamatan Kopang mengalami permasalahan dalam pembelajaran Matematika. Berdasarkan observasi yang peneliti lakukan di kelas VI Semester I SDN Mumbang Kecamatan Kopang Tahun Pelajaran 2019/2020, ternyata ketika pembelajaran Matematika berlangsung siswa terlihat kurang tertarik mengikuti pembelajaran dikarenakan metode mengajar guru yang monoton, tidak melibatkan siswa secara langsung dalam proses pembelajaran. Pembelajaran Matematika terasa sangat membosankan bagi siswa. Guru hanya memberikan ceramah tentang konsep Matematika tanpa adanya keikutsertaan siswa dalam proses pembelajaran Matematika. Siswa pun kurang memahami konsep dasar pembelajaran Matematika yang diajarkan yang mengakibatkan ketika diberikan tugas siswa mengalami kesulitan mengerjakan tugas tersebut yang berakibat pada rendahnya hasil belajar siswa dalam pembelajaran Matematika sebelum tindakan atau Pra Siklus yaitu dari 22 orang siswa yang mendapatkan nilai $\leq 69$ yaitu 12 orang siswa $(54,55 \%)$ dan 10 orang siswa $(45,45 \%)$ yang memperoleh nilai $\geq 70$, Nilai tertinggi 70 dan nilai terendah 40 .

Faktor yang menyebabkan yaitu guru kurang memanfaatkan media yang ada, metode yang monoton yang selalu ditawarkan dalan setiap pembelajaran sehingga mengakibatkan siswa kurang termotivasi, secara tidak langsung hasil belajar siswa rendah.

Setiap proses pembelajaran yang mengalami kesulitan atau pun hambatan memerlukan solusi untuk pemecahannya. Guru dituntut untuk menguasai berbagai macam teori belajar maupun metode pembelajaran yang dapat digunakan dalam menyampaikan materi pembelajaran dan mengatasi kesulitan pembelajaran.

Salah satu teori belajar yang dapat diterapkan dalam pembelajaran adalah teori belajar Dienes. Teori belajar Dienes mengemukakan bahwa tiap-tiap konsep atau prinsip dalam Matematika yang disajikan dalam bentuk konkret akan dapat dipahami dengan baik. Ini mengandung arti bahwa jika benda-benda atau objek-objek dalam bentuk permainan akan sangat berperan bila dimanipulasi dengan baik dalam pengajaran Matematika. Pembelajaran menggunakan teori belajar Dienes merupakan rangkaian pembelajaran dari kongkret ke abstrak (Nymas Aisyah, dkk., 2007: 2.7).

Pada dasarnya anak usia SD merupakan usia seseorang senang melakukan permainan. Penerapan teori Belajar Dienes dalam bentuk permainan akan melibatkan siswa secara langsung dalam pembelajaran. Dalam permainan melibatkan benda-benda konkret yang akan dimanipulasi siswa untuk dapat memahami konsep dasar Matematika. Hal ini akan dapat meningkatkan motivasi dan prestasi belajar siswa dalam pembelajaran Matematika.

Dipilihnya penerapan teori belajar dienes merupakan solusi yang sangat tepat untuk digunakan kelas VI untuk memecahkan masalah belajar Matematika yang dihadapi siswa SDN Mumbang Kecamatan Kopang tahun Pelajaran 2019/2020. Dengan penerapan teori belajar dienes ikut berperan dalam pembelajaran secara langsung dan hal tersebut akan membuat siswa merasa senang dalam proses pembelajaran,ini merupakan kunci untuk meraih keberhasilan bagi guru dan siswa.

Jika kondisi ini benar-benar terjadi,maka dengan penerapan teori belajar dienes dapat meningkatkan motivasi dan prestasi belajar 
siswa dan keaktifan siswa dalam proses belajar,karena dengan penerapan teori belajar dienes ini siswa akan mengalami proses belajar secara nyata atau abstrak,maka hal ini akan selalu dikenang dalam memorinya sampai kapanpun. Keadaan inilah yang membuat penulis terpanggil untuk melakukan penelitian tentang "Penerapan Teori Belajar Dienes Untuk Meningkatkan Prestasi Belajar Matematika Materi Pokok Lingkaran Siswa Kelas VI Semester I SDN Mumbang Kecamatan Kopang Tahun Pelajaran 2019/2020 adalah:

Rumusan masalah penelitian ini

"Bagaimanakah Matode dienes dapat meningkatkan prestasi belajar Matematika siswa kelas VI Semester I SDN Mumbang Kecamatan Kopang Tahun Pelajaran 2019/2020 ?"

Tujuan penelitian ini adalah:(1).Untuk mengetahui cara meningkatkan prestasi belajar Matematika siswa kelas VI Semester I SDN Mumbang Kecamatan Kopang Tahun Pelajaran 2019/2020. (2)Untuk mengetahui penerapan teori belajar dienes pada mata pelajaran Matematika. (3). Untuk mengetahui keefektifan penerapan teori belajar dienes dalam meningkatkan motivasi dan prestasi belajar Matematika siswa kelas VI Semester I SDN Mumbang Kecamatan Kopang Tahun Pelajaran 2019/2020.

(1). Manfaat teoritisPenelitian ini di harapkan dapat dijadikan acuan untuk meneliti di bidang yang sama untuk penelitian selanjutnya.(2). Manfaat praktis(a).Bagi siswa, hasil penelitian ini semoga dapat memberikan manfaat berupa informasi mengenai penerapan teori belajar dienes dalam pembelajaran Matematika.(b).Bagi Guru, Hasil penelitian ini diharapkan dapat bermanfaat bagi guru sekolah dasar sebagai masukan dalam mengembangkan metode pembelajaran terutama dalam pembelajaran Matematika. (c). Bagi Sekolah Dapat membantu sekolah untuk berkembang karena adanya peningkatan / kemajuan pada diri guru, dan peserta didik di sekolah itu sendiri.

\section{KAJIAN PUSTAKA}

Prestasi belajar adalah sebuah kalimat yang terdiri dari dua kata, yakni "prestasi" dan "belajar", mempunyai arti yang berbeda. Untuk memahami lebih jauh tentang pengertian prestasi belajar, peneliti menjabarkan makna dari kedua kata tersebut.

Menurut WJS. Poerwadarminta (2006: 901) "Prestasi adalah hasil yang telah di capai (dilakukan, dikerjakan dan sebagainya)". Menurut Raka joni (dalam Rakhmat, dkk., 2006 : 209) mengemukaan bahwa prestasi belajar adalah kegiatan belajar siswa untuk memperoleh pengetahuan, keterampilan, sikap serta nilai- nilai.Prestasi merupakan kumpulan hasil akhir dari suatu yang pekerjaan yang telah dilakukan. Prestasi tidak datang begitu saja, untuk mendapatkannya harus melalui perjuangan yang keras. "Prestasi adalah suatu kegiatan yang telah dikerjakan, diciptakan, baik secara individual maupun kelompok" (Syaiful Bahri Djamarah, 1994:19), prestasi tidak akan dicapai bila seseorang tidak melakukan kegiatan.

Dari pendapat di atas dapat ditarik kesimpulan bahwa prestasi merupakan hasil usaha yang dicapai seseorang yang terlebih dahulu melakukan kegiatan.

Menurut Slameto. (2003 : 2) "Belajar adalah suatu proses yang di lakukan seseorang untuk memperoleh suatu perubahan tingkah laku yang baru secara keseluruhan, sebagai hasil pengalaman sendiri dalam interaksi dengan lingkungannya ".Belajar adalah berusaha (berlatih) supaya mendapat suatu kepandaian(ilmu)" (Poerwadarminto, 2006:121). Dalam hal ini kepandaian bisa ditunjukan dengan prestasi yang memuaskan dari usaha yang diraihnya sendiri.

Belajar merupakan suatu proses panjang dari lahir hingga akhir hayat. Belajar dapat diperoleh melalui pendidikan formal maupun nonformal yaitu pendidikan dari keluarga dan lingkungannya sampai pendidikan sekolah yang mempunyai tujuan untuk merubah tingkah laku, sikap, keterampilan, kebiasaan serta perubahan seseorang kearah yang lebih baik.

Menurut Bloom (Cece Rakhmat, dkk., 2006 : 209) prestasi belajar merupakan hasil perubahan tingkah laku meliputi tiga ranah kognitif, afektif, dan psikomotor. Pendapat lain mengatakan bahwa prestasi belajar mencerminkan sejauh mana siswa telah dapat 
mencapai tujuan yang telah di tetapkan pada setiap bidang studi. Gambaran prestasi siswa dapat di nyatakan dengan angka dari 0 sampai 10 ( Arikunto, 2001: 62)."Prestasi belajar adalah sebagai hasil dari usaha seseorang untuk mengubah dirinya dengan jalan memperoleh kecakapan baru dan hasil perubahan itu diperoleh melalui latihan dan pengalaman" adalah pendapat dari (Oemar Hamalik, 1983:11).

Hasil usaha kegiatan belajar yang dinyatakan dalam bentuk symbol, angka, huruf maupun kalimat yang dapat mencerminkan hasil yang sudah dicapai oleh setiap siswa dalam periode tertentu adalah prestasi belajar" menurut (Syaiful Bahri Djamarah, 1994:231), sedangkan pendapat lain menyatakan bahwa "prestasi belajar merupakan hasil maksimal yang dicapai akibat kemampuan dari seseorang untuk melakukan aktifitas" (Syaiful Anwar, 1997:11).

Dari uraian di atas dapat disimpulkan pengertian prestasi belajar adalah hasil yang di peroleh berupa kesan-kesan yang mengakibatkan perubahan dalam diri individu sebagai hasil dari aktivitas siswa dalam belajar.

\section{Teori Belajar Dienes}

Dienes (Nymas Aisyah, dkk., 2007 : 2-7) berpendapat bahwa pada dasarnya Matematika dapat dianggap sebagai studi tentang struktur, memisah-misahkan hubungan-hubungan di antara strukturstruktur dan mengkatagorikan hubunganhubungan di antara struktur-struktur.

Perkembangan konsep Matematika menurut Dienes (Nymas Aisyah, dkk., 2007 : 2-8) dapat dicapai melalui pola berkelanjutan, yang setiap seri dalam rangkaian kegiatan belajar dari kongkret ke simbolik. Tahap belajar adalah interaksi yang direncanakan antara yang satu segmen struktur pengetahuan dan belajar aktif, yang dilakukan melalui media Matematika yang disain secara khusus. Menurut Dienes, permainan Matematika sangat penting sebab operasi Matematika dalam permainan tersebut menunjukkan aturan secara kongkret dan lebih membimbing dan menajamkan pengertian Matematika pada anak didik. Dapat dikatakan bahwa objek-objek kongkret dalam bentuk permainan mempunyai peranan sangat penting dalam pembelajaran Matematika jika dimanipulasi dengan baik. Menurut Dienes (Nymas Aisyah, dkk., 2007 : 2-8), konsepkonsep Matematika akan berhasil jika dipelajari dalam tahap-tahap tertentu. Dienes membagi tahap-tahap belajar menjadi tahap, yaitu

\section{Tahapan Teori Dienes}

Dalam setiap tahap belajar, tahap yan paling awal dari pengembangan konsep bermula dari permainan bebas. Permainan bebas merupakan tahap belajar konsep yang aktifitasnya tidak berstruktur dan tidak diarahkan. Anak didik diberi kebebasan untuk mengatur benda. Selama permainan pengetahuan anak muncul. Dalam tahap ini anak mulai membentuk struktur mental dan struktur sikap dalam mempersiapkan diri untuk memahami konsep yang sedang dipelajari. Misalnya dengan diberi permainan block logic, anak didik mulai mempelajari konsep-konsep abstrak tentang warna, tebal tipisnya benda yang merupakan ciri/sifat dari benda yang dimanipulasi.

Dalam permainan yang disertai aturan siswa sudah mulai meneliti pola-pola dan keteraturan yang terdapat dalam konsep tertentu. Keteraturan ini mungkin terdapat dalam konsep tertentu tapi tidak terdapat dalam konsep yang lainnya. Anak yang telah memahami aturan-aturan tadi. Jelaslah, dengan melalui permainan siswa diajak untuk mulai mengenal dan memikirkan bagaimana struktur Matematika itu. Makin banyak bentuk-bentuk berlainan yang diberikan dalam konsep tertentu, akan semakin jelas konsep yang dipahami siswa, karena akan memperoleh hal-hal yang bersifat logis dan matematis dalam konsep yang dipelajari itu. Menurut Dienes,untuk membuat konsep abstrak, anak didik memerlukan suatu kegiatan untuk mengumpulkan bermacammacam pengalaman, dan kegiatan untuk yang tidak relevan dengan pengalaman itu. Contoh dengan permainan block logic, anak diberi kegiatan untuk membentuk kelompok bangun yang tipis, atau yang berwarna merah, kemudian membentuk kelompok benda berbentuk segitiga, atau yang tebal, dan 
sebagainya. Dalam membentuk kelompok bangun yang tipis, atau yang merah, timbul pengalaman terhadap konsep tipis dan merah, serta timbul penolakan terhadap bangun yang tipis (tebal), atau tidak merah (biru), hijau, kuning).

Dalam mencari kesamaan sifat siswa mulai diarahkan dalam kegiatan menemukan sifat-sifat kesamaan dalam permainan yang sedang diikuti. Untuk melatih dalam mencari kesamaan sifat-sifat ini, guru perlu mengarahkan mereka dengan menstranslasikan kesamaan struktur dari bentuk permainan lain. Translasi ini tentu tidak boleh mengubah sifat-sifat abstrak yang ada dalam permainan semula. Contoh kegiatan yang diberikan dengan permainan block logic, anak dihadapkan pada kelompok persegi dan persegi panjang yang tebal, anak diminta mengidentifikasi sifat-sifat yang sama dari benda-benda dalam kelompok tersebut (anggota kelompok).

Representasi adalah tahap pengambilan sifat dari beberapa situasi yang sejenis. Para siswa menentukan representasi dari konsep-konsep tertentu. Setelah mereka berhasil menyimpulkan kesamaan sifat yang terdapat dalam situasi-situasi yang dihadapinya itu. Representasi yang diperoleh ini bersifat abstrak, Dengan demikian telah mengarah pada pengertian struktur Matematika yang sifatnya abstrak yang terdapat dalam konsep yang sedang dipelajari. Permainan dengan Simbolisasi (Symbolization).Simbolisasi termasuk tahap belajar konsep yang membutuhkan kemampuan merumuskan representasi dari setiap konsep-konsep dengan menggunakan

Formalisasi merupakan tahap belajar konsep yang terakhir. Dalam tahap ini siswasiswa dituntut untuk mengurutkan sifat-sifat konsep dan kemudian merumuskan sifat-sifat baru konsep tersebut, sebagai contoh siswa yang telah mengenal dasar-dasar dalam struktur Matematika seperti aksioma, harus mampu merumuskan teorema dalam arti membuktikan teorema tersebut. Contohnya, anak didik telah mengenal dasar-dasar dalam struktur Matematika seperti aksioma, harusmampu merumuskan suatu teorema berdasarkan aksioma, dalam arti membuktikan teorema tersebut. Karso (1999:1.20) menyatakan, pada tahap formalisasi anak tidak hanya mampu merumuskan teorema serta membuktikannya secara deduktif, tetapi mereka sudah mempunyai pengetahuan tentang sistem yang berlaku dari pemahaman konsep-konsep yang terlibat satu sama lainnya. Misalnya bilangan bulat dengan operasi penjumlahan peserta sifat-sifat tertutup, komutatif, asosiatif, adanya elemen identitas, dan mempunyai elemen invers, membentuk sebuah sistem Matematika.

\section{Langkah -Langkah Pembelajaran Teori Dienes}

Dalam tahap ini siswa di bagi dalam beberapa kelompok, dalam setiap kelompok mereka di beri kebebasan untuk memilih dan mengambil Lingkaran yang sudah di disain beraneka warna sehingga siswa bebas memilih warna apa yang mereka sukai.(1)Permainan yang menggunakan aturan (games)setelah Lingkaran yang dipilih oleh siswa guru memberi suatu arahan untuk menyebutkan Lingkaran yang di ambil.(2)Permainan kesamaan sifat Setelah menentukan Lingkaran yang mereka ambil kemudian mereka menentukan sifat -sifat dari Lingkaran tersebut, seperti menentukan perbedaan antara Lingkaran yang satu dengan yang lain dari segi sisi dan sudut. (3)Setelah mereka menentukan jenis Lingkaran di ambil, mengetahui sisi dansudut, mereka dengan kelompoknya akan maju mempersentasikan hasil penelitian berdasarkan kelompoknya.

Kelebihan dan kekurangan

1.Kelebihan (a) Siswa dapat bermain sambil belajar (b) Terjadinya kompetensi antar siswa yang mengakibatkan adanya motivasi 2.kekurangan (a) Guru merasa kualahan dalam mengarahkan suatu pembelajaran.(b) Adanya kecemburuan antar siswa yang lain apabila salah satu siswa yang lebih unggul.

\section{METODE PENELITIAN}

Penelitian ini dilaksanakan pada siswa kelas VI Semester I SDN Mumbang Kecamatan Kopang Tahun Pelajaran 2019/2020 pada bulan Agustus sampai Oktober 2019 Penelitian ini dilaksanakan Siswa kls VI Semester I SDN Mumbang Kecamatan Kopang tahun pelajaran 
2019/2020 berjumlah 22 orang siswa. Data sementara siswa yang tuntas sebanyak 14 siswa dari 22 siswa, dan yang belum tuntas sebanyak8 orang siswa. Subjek penelitian ini dengan mempertimbangkan tingkat kemampuan siswa pada tingkat rendah,sedang, tinggi, ini dimaksudkan agar hasil penelitian memperoleh hasil yang akurat,terpercaya dan dapat di pertanggung jawabkan. Observer yang bertugas dalam mengobservasi siswa dan guru adalah teman sejawat.

Penelitian tindakan kelas ini direncanakan dilaksanakan dalam 2 siklus. Jika siklus pertama kurang berhasil maka dilanjutkan dalam siklus kedua dan seterusnya.Penelitian tindakan ini menggunakan model Kurt Lewin sebagai acuan pokok penelitian tindakan kelas. Konsep pokok penelitian tindakan Kurt Lewin terdiri dari empat komponen, yaitu (a) perencanaan (planning), (b) tindakan (acting), (c) pengamatan (observing), dan (d) refleksi (reflecting). Untuk memperjelas fase- fase dalam penelitian tindakan, stephen kemmis (Dalam suharsimi Arikunto, 2006: 16) menggambarkan dalam siklus spiral, sebagaimana tampak dalam Gambar berikut:

Langkah - Langkah Penelitian

\section{Tahap Perencanaan}

Pada tahap ini yang dilakukan adalah membuat perencanaan semua proses yang dibutuhkan pada saat pelaksanaan penelitian berlangsung. Penelitian tindakan kelas ini dilaksanakan dalam siklus. Masing-masing siklus terdiri beberapa tahap yakni dimulai dari perencanaan, pelaksanaan tindakan, observasi dan evaluasi serta refleksi. Untuk lebih jelasnya dapat dilihat prosedur penelitian untuk tiap siklus sebagai berikut.Kegiatan yang dilaksanakan pada tahap perencanaan penelitian ini adalah :(a) Mempelajari Kompetensi Dasar dan Standar Kompetensi untuk siswa kelas VI Semester I dalam BSNP.(b)Menyusun Rencana Pelaksanaan Pembelajaran (RPP).

(c)Menyusun Lembar Observasi, untuk melihat bagaimana kegiatan guru dan aktivitas siswa selama proses belajarmengajar.(d)Menyusun tes hasil belajar dalam bentuk melengkapi untuk mengetahui hasil belajar siswa.

\section{Pelaksanaan}

Pada tahap ini, yaitu melaksanakan kegiatan belajar mengajar dikelas sesuai dengan rencana yang telah dituangkan dalam rencana pelaksanaan pembelajaran (RPP). Rencana pelaksanaan pembelajaran yang diterapkan disesuaikan dengan teori belajar Gagne yang memaparkan kegiatan awal, kegiatan inti, dan kegiatan akhir.

\section{Observasi}

Kegiatan observasi atau pengamatan dilaksanakan pada saat proses pembelajaran berlangsung untuk mengetahui dan memperoleh gambaran lengkap secara objektif tentang perkembangan proses pembelajaran dan ada tidaknya pengaruh dari tindakan (aksi) yang dipilih terhadap kondisi kelas tempat dilaksanakannya tindakan (Susilo, 2007).Kegiatan observasi dilakukan secara kontinu setiap kali pembelajaran berlangsung, observasi dilaksanakan oleh Guru kelas untuk mengamati kegiatan guru (peneliti) dan siswa selama proses pembelajaran berlangsung menggunakan lembar observasi yang telah disiapkan Evaluasi dilaksanakan pada akhir pertemuan setelah materi pembelajaran selesai diajarkan. Peneliti di bantu oleh guru kelas dalam mengevaluasi hasil belajar Matematika siswa.

\section{Refleksi}

Refleksi dilakukan setelah evaluasi dilaksanakan. Peneliti sebagai pengajar bersama guru yang bertindak sebagai observer, mengkaji kekuarangan dari tindakan yang telah diberikan. Hal ini dilakukan dengan cara melihat data hasil evaluasi yang dicapai siswa pada siklus I dan hasil observasi yang dilakukan saat pelaksanaan tindakan siklus I berlangsung. Jika berdasarkan hasil refleksi ini tindakan pada siklus I belum berhasil maka dilanjutkan ke siklus II begitu seterusnya.

\section{Hasil Penelitian}

Penelitian tindakan kelas ini dilakukan untuk mengetahui hasil belajar siswa kelas VI Semester I SDN Mumbang Kecamatan Kopang pada materi macam - macam Lingkaran dengan menggunakan teori belajar dienes. Dari hasil evaluasi belajar diperoleh 
data kuantitatif dan data kualitatif yang diperoleh dari hasil observasi tentang aktivitas belajar siswa. Data - data tersebut selanjutnya dianalisis menggunakan alat peraga dan rumus yang telah ditetapkan sebelumnya. Adapun analisis data dari siklus I dan siklus II akan dipaparkan sebagai berikut:

\section{Siklus I}

a. Perencanaan: Pada tahap ini yang dilakukan adalah menyiapkan rencana pembelajaran yaitu membuat scenario pembelajaran, ini merupakan awal dari proses untuk melaksanakan suatu tindakan penelitian. Selanjutnya menyiapkan bahan - bahan seperti buku panduan yang relevan dengan materi pembelajaran dan menyiapkan bahan - bahan pertanyaan pada tengah - tengah pembelajaran berlangsung, untuk menambah motivasi siswa belajar pada materi ini. Pada tahap ini, peneliti menyiapkan hal - hal sebagai berikut: (1)Menyiapkan rencana pembelajaran, (2)Membuat skenario pembelajaran siklus I, (3)Membuat lembar observasi siklus I, (4)Merancang alat evaluasi siklus I, (5)Merencanakan analisis hasil siklus I.

b. Pelaksanaan : Implementasi tindakan ini merupakan gambaran secara rinci terhadap kegiatan dengan metode belajar dienes yang di laksanakan sesuai dengan skenario pembelajaran kegiatan yang di lakukan guru meliputi (1)Kegiatan awal (2)Kegiatan inti (3) Kegiatan akhir

\section{c. Observasi}

\section{Proses belajar mengajar siklus pertama pertemuan Tabel 4.1} pertama dilakukan pada tanggal 7 September 2015Hasil Evaluasi Belajar Siswa Siklus I dengan alokasi waktu 2 x 35 menit, materi yang dibahas tentang macam - macam Lingkaran. Adapun hasil observasi aktivitas siswa tercantum dalam lampiran 9 namun rincian dari hasil lembar observasi siswa adalah sebagai berikut: (a). Kesiapan siswa dalam menerima materi pembelajaran sudah cukup baik tetapi masih ada siswa yang belum siap karena masih terpengaruh dengan situasi luar kelas. (b). Interaksi siswa dalam kelompok sudah baik namun siswa yang memperoleh nilai $\geq 70$ sedangan masih ada siswa yang kurang aktif dalam siswa yang memperoleh nilai $\leq 69$, baru 8 kelompoknya tersebut. (c).Interaksi siswa dengansiswa $(36,64 \%)$ ini menunjukkan bahwa guru saat bimbingan kelompok masih kurang ketuntasan secara klasikal belum dicapai disebabkan siswa masih malu dalam meresponyaitu $80 \%$.

pertanyaan dari guru. (d)Interaksi siswa dengan guru d. Refleksi 
Dilihat dari hasil yang diperoleh pada siklus I, ternyata belum mencapai hasil yang diharapkan. Untuk itu, peneliti

melanjutkan pemebelajaran pada tahap berikunya yaitu pada siklus II. Adapun keterangan - keterangan yang terdapat pada siklus I akan diperbaiki pada siklus kedua diantaranya yaitu: (a).Memperbaiki, kesiapan siswa dalam menerima pelajaran dengan mengingat kembali hasil evaluasi yang diperoleh siswa pada materi yang diterima sebelumnya,(b).Memeberikan bimbingan secara optimal kepada siswa yang mengalami kesulitan dalam menerima pelajaran.C.Agar siswa termotivasi dalam proses pembelajaran, maka guru memberikan pujian dan nilai kepada sisiwa yang aktif. (d).Guru merancang relevansi materi yang baik dan menarik, sehingga siswa dapat merasakan manfaat yang baik dari pembelajaran yang telah diterima.

\section{Siklus II}

a. Perencanaan :Kegiatan pembelajaran pada siklus II hampir sama dengan siklus I, namun pada siklus II di lakukan perbaikanperbaikan atau penyempurnaan proses pembelajaran berdasarkan hasil siklus I. Kegiatan pembelajaran pada siklus II di laksanakan 1 x pertemuan pada Hari senin 14 September 2015 pada akhir pertemuan di adakan evaluasi

Adapun kegiatan pada siklus II ini adalah sebagai berikut:

a.Perencanaan :Kegiatan yang di lakukan dalam tahap perencanaan adalah:(1).Menentukan pokok bahasan(2).Menyusun rencana pelaksanaan pembelajaran siklus II(3).Mengembangkan skenario pembelajaran berdasarkan teori dienes(4).Menyususn LKS( lembar kerja siswa)(5).Menyusun lembar observasi aktivitas guru dan siswa(6).Menyusun pedoman penskoran evaluasi siklus I(7)Membuat daftar nilai evaluasi siklus I

b.Pelaksanaan :Pada tahap ini, perencanaan yang dilakukan lebih matang dari sebelumnya, yaitu dengan melihat kekurangakekurangan yang terjadi pada siklus pertama sebagai penyebab rendahnya hasil belajar pada materi macam - macam Lingkaran, akan diusahakan perbaikan pada tahap berikutnya yaitu pada siklus II, dengan persiapan sebagai berikut:

1.Kegiatan awal : Pada tahap ini guru melaksanakan kegiatan pembelajaran sesuai dengan skenario yang telah di susun dengan tambahan perbaikan - perbaikan hasil refleksi.untuk lebih meningkatkan aktivitas siswa guru memberikan motivasi kepada siswa melalui lagu lagu yang bernadakan riang. Guru kemudian memberikan informasi materi yang akan di bahas pada pertemuan hari ini. Keantosiasan siswa dalam belajar menjadikan suasana kelas menjadi hidup dan guru lebih bersemangat dalam mengajar hampir semua siswa berani mengajukan dan menjawab pertanyaan meskipun ada beberapa siswa yang hanya memperhatikan saja.

2.Kegiatan inti : Pada kegiatan inti guru menjelaskan tetang sisi dan sudut dari Lingkaran sederhana, guru meminta siswa untuk menyebutkan Lingkaran yang sudah di sediakan, kemudian guru membagi siswa menjadi beberapa kelompok, pada saat siswa mengelompokkan diri dengan teman kelompoknya suasana sedikit gaduh sehingga guru memberikan peringatan kepada siswa untuk kembali ke teman kelompoknya masing - masing, guru membagikan siswa media sederhana yang berbentuk Lingkaran sederhana, setiap kelompok mengambil Lingkaran tersebut, kemuadian di diskuikan dengan teman kelomponya berapa sisi dna sudutnya, pada kahir pembelajaran salah satu wakil dari kelomok maju unuk mempersentasikan hasil pengamatan yang berdasarkan Lingkaran yang di ambil, seperti persegi memiliki sudut berapa dan sisi berapa, ketika kegiatan ini berlangsung ada beberapa siswa sangat aktif dalam menyimak hasil persentasi wakil kelompok masing - masing sehingga materi yang di cerna lebih mengena pada siswa. Kenudian guru membrikan penghargaan berupa tepuk tangan agar siswa lebih termotivasi.

3.Kegiatan akhir : Di bagian kegiatan akhir, guru dan siswa melakukan reflesi tentang pembelajaran yang telah di laksanakan. Pada kegiatan ini kegiatan guru maupun kegiatan siswa sudah sangat aktif .setelah itu guru memberikan kesimpulan sekaligus memberikan penguatan terhadap materi yang 
di ajarkan agar materi yang di sampailan pada siswa lebih melekat dalam konitifnya.

\section{c. observasi}

a. Hasil observasi aktivitas belajar siswa :Proses belajar siklus II pertemuan pertama dilaksanakan pada Hari Senin, 14 September 2015 dengan alokasi waktu 3 x 35 menit, materi yang dibahas pada siklus kedua pertemuan pertama adalah mengenai sisi dari Lingkaran sederhana. Adapun hasil observasi aktivitas belajar siswa dapat dilihat pada observasi sebagai berikut:(1).Kesiapan siswa menerima materi pembelajaran sudah baik, sudah banyak siswa yang membawa buku panduan dan memperhatikan penjelasan guru diawal pembelajaran sudah baik serta siswa sudah fokus dalam menerima materi pembelajaran, sehingga proses belajar mengajar berjalan dengan baik.(2).Interaksi siswa dalam kelompok sudah baik, siswa sudah mau mengeluarkan pendapatnya kepada teman kelompoknya.(3).Interaksi siswa dengan guru saat bimbingan kelompok sudah baik pula, siswa sudah bisa mengeluarkan pendapatnya untuk menanyakan hal - hal yang belum dimengerti.(4).Interaksi siswa dengan guru secara kelasikal sudah cukup baik, siswa sudah berani mengeluarka ide untuk bertanya dan menjawab apa yang ditanyakan oleh guru.(5).Kemampuan siswa menggunakan alat peraga sudah baik, siswa sudah mampu mengoperasikan sendiri cara penggunaan alat peraga yang sesuai dengan teori belajar dienes. (6).Partisipasi siswa dalam menyimpulkan hasil belajar sudah cukup baik, siswa sudah bisa mencoba menyimpulkan hasil belajar dan menambah kesimpulan belajar walaupun belum sempurna.

Hasil rata-rata persentase aktivitas siswa pada siklus kedua pertemuan pertama sebesar 2,89 (dilampiran 18), ini berarti bahwa kategori aktivitas siswa dalam pembelajaran siklus kedua pertemuan pertama tergolong sangat aktif. Proses belajar mengajar siklus II pertemuan kedua dilaksanakan pada Hari Rabu, 16 September 2015 dengan alokasi waktu 3 x 35 menit, berdasarkan data hasil observasi aktivitas siswa pada siklus kedua pertemuan kedua menunjukkan adanya peningkatan yang baik.kekurangan - kekurangan pada pertemuan pertama dapat teratasi, terlihat dari data-data persentase aktivitas siswa sebesar 3,0, berarti kategori aktivitas siswa dalam pembelajaran siklus kedua pertemuan kedua sudah tergolong sangat aktif. Dari tabel di atas diperoleh ratarata persentase aktivitas siswa pada siklus dua pertemuan pertama adalah 2,89 dan pertemuan kedua adalah 3,0 berdasarkan penggolongan aktivitas siswa sebelumnya maka rata-rata persentase aktivitas siswa pada siklus kedua tergolong sangat aktif.

Tabel 4.2.

Hasil Evaluasi Belajar Siswa Siklus II

\begin{tabular}{|c|r|r|r|r|r|r|r|}
\hline $\begin{array}{c}\text { Jum } \\
\text { lah } \\
\text { Siswa }\end{array}$ & $\begin{array}{r}\text { Skor } \\
\text { tertinggi }\end{array}$ & $\begin{array}{r}\text { Skor } \\
\text { Teren } \\
\text { dah }\end{array}$ & $\begin{array}{r}\text { Nilai } \\
\text { Rata-Rata }\end{array}$ & $\begin{array}{r}\text { Sis } \\
\text { wa } \\
\mathrm{Tu} \\
\text { ntas }\end{array}$ & $\begin{array}{r}\mathrm{Ti} \\
\%\end{array}$ & $\begin{array}{c}\text { dak } \\
\text { Tuntas }\end{array}$ & $\%$ \\
\hline 22 & 90 & 60 & 77,27 & 20 & $\begin{array}{r}9 \\
0,91\end{array}$ & $\begin{array}{c}9 \\
0\end{array}$ \\
\hline
\end{tabular}

Dari Tabel di atas dapat dilihat Hasil belajar siswa pada siklus II adalah 20 orang siswa $(90,91 \%)$ siswa yang memperoleh nilai $\geq 70$ sedangan siswa yang memperoleh nilai $\leq$ 69 , baru 2 orang siswa $(9,09 \%)$ ini menunjukkan bahwa peningkatan prestasi sangat signifikandimana ketuntasan secara klasikal sudah dicapai 90,91 \%. Hasil ini sudah mencapai target yang di inginkan yaitu di atas $80 \%$, dan tidak perlu dilanjutkan ke siklus berikutnya.

\section{d.Refleksi}

Setelah melihat hasil observasi yang diperoleh pada siklus II, kekurangan - kekurangan pada siklus pertama dapat teratasi, hasil evaluasi siklus II lebih besar dari standar ketuntasan klasikal yaitu $80 \%$. Dengan batas nilai minimal yang diperoleh siswa secara individual minimal 70 dan aktivitas siswa tergolong aktif. Maka tujuan pada penelitian ini dinyatakan tercapai, sehingga siklus penelitian ini dihentikan sampai siklus dua.

\section{Pembahasan}

\section{Siklus I}

Berdasarkan hasil analisis yang telah didapatkan dari siklus I menunjukkan adanya peningkatan dan perbaikan dalam proses belajar mengajar. Pada siklus I persentase ketuntasan belajar menunjukkan peningkatan dari $(36,36 \%)$ pada pra siklus 
menjasi 63,64 \% pada siklus I. Tapi masih belum mencapai ketuntasan belajar klasikal yang telah ditetapkan yaitu $80 \%$. Ini disebabkan karena kurang siapnya siswa menerima materi pembelajaran, sehingga siswa sulit memahami dan memnyerap materi pembelajaran yang disampaikan oleh guru. Sebagian besar siswa masih kurang komunikasi antara teman kelompoknya maupun dengan guru ketika diberikan bimbingan oleh guru. Disini juga siswa masih banyak yang belum bisa memahami secara baik penggunaan dari alat praga yang sesuai dengan teori belajar dienes. Serta siswa masih malu untuk mengemukakan pendapat mereka disaat penyimpulan materi yang telah dijelaskan oleh guru. Disini dapat dilihat analisis akivitas guru pada siklus I pertemuan pertama sebesar 2,4 dan persentase aktivitas guru pada siklus I pertemuan kedua sebesar 2,5 ini menunjukkan adanya peningkatan yang dilakukan oleh guru dalam proses mengajar. Berdasarkan analisis siklus I, menunjukkan bahwa persentase aktivitas belajar siswa pada pertemuan pertama sebesar 2,11 yang tergolong aktif dan persentase aktivitas siswa pada pertemuan kedua sebesar 2,25 yang tergolong aktif juga, untuk mengatasi hal ini guru melakuakan perbaikan - perbaikan dalam pemblajaran dan hal - hal yang masih dianggap kurang yaitu dengan memberikan motivasi dan bimbingan yang lebih baik lagi pada siswa dalam belajar.

\section{Siklus II}

Pada siklus II guru dan siswa mengadakan perbaikan-perbaikan pada proses belajar mengajar sesuai dengan rencana pembelajaran dan lembar observasi. Guru lebih menekanakan pada siswa untuk lebih aktif dalam proses pembelajaran. Serta guru akan memberikan motivasi dan bimbingan yang optimal pada siswa agar yang masih sulit menerima materi pelajaran, sehingga tercapai ketuntasan belajar yang aharapkan yaitu sebaesar $80 \%$ pada siklus II. Pada siklus kedua, siswa telah menunjukkan keterlibatannya secara aktif walaupun tidak keseluruhannya. Misalnya cukup aktif dalam mengeluarkan pendapatnya untuk bertanya terhadap materi-materi yang belum dimengerti. Disini juga dapat dilihat interaksi antara siswa dengan siswa dalam kelompok, antara siswa dengan guru disaat bimbingan kelompok sudah kelihatan lebih aktif, dan dalam pengoperasian alat praga suadah baik karena siswa pada siklus dua lebih memperhatikan dan lebih fokus dalam menerima penjelasan yang diberikan oleh guru. Oleh karena itu, dari analisis siklus II diperoleh persentase ketuntasan belajar sebesar 90,91 \%. Ini menunujukkan tercapainya ketuntasan klasikal yang telah ditetapkan yaitu $80 \%$. Sedangkan analisis akivitas guru pada siklus II pertemuan pertama sebesar 2,83 dan persentase aktivitas guru pada siklus II pertemuan kedua sebesar 3,0 ini menunjukkan adanya peningkatan yang dilakukan oleh guru dalam proses mengajar.

Disini juga dapat dilihat persentase ratarata aktivitas siswa pada siklus kedua pertemuan pertama sebesar 2,89 yang tergolong sangat aktif dan pada siklus kedua pertemuan kedua 3,0 yang tergolong sangat aktif. Sehingga jumlah siswa yang sudah tuntas belajar lebih dari $80 \%$ dan aktivitas siswa tergolong sangat aktif maka pada siklus II ini dinyatakan tuntas dan penelitian dihentikan. Perbedaaan siklus pertama dan kedua dapat dilihat pada tabel di bawah ini:

Tabel 4.3.

\section{Hasil Belajar Pra Siklus,Siklus I dan Siklus} II

\begin{tabular}{|c|c|c|c|c|}
\hline Sillus & Mian eftumgen & Milial Teremala & Milindan-R & 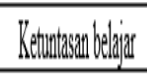 \\
\hline Perasildus & 75 & 40 & 36.7 & 3666 \\
\hline Sillwis! & 80 & 40 & 6.27 & 63,140 \\
\hline Sillas II & 9 & 60 & 71,27 & 90,9\% \\
\hline
\end{tabular}

Sesuai dengan hasil penelitian, dapat dinyatakan bahwa pelajaran dengan menerapkan teori belajar dienes dapat meningkatkan Prestasi belajar siswa pada materi Lingkaran.

\section{KESIMPULAN DAN SARAN Kesimpulan}

Teori belajar dienes adalah teori belajar yang diterapkan dalam proses pembelajaran untuk mempermudah danmempercepat pemahaman siswa. Berdasarkan hasil penelitian yang telah peneliti lakukan dapat 
diambil kesimpulan yaitu: penerapan teori belajar dienes dapat meningkatkan hasil belajar Matematika kelas VI Semester I SDN Mumbang Kecamatan Kopang tahun Pelajaran 2019/2020. Hal ini dapat dibuktikan dengan peningkatan hasil belajar pada siklus I dan siklus II. Adapun hasil yang diperoleh dari 22 orang siswa, pada siklus I siswa yang tuntas 14 orang dan siswa yang tidak tuntas 8 orang, dengan persentase ketuntasan kelasikal $63,64 \%$. Sedangkan pada siklus II siswa yang tuntas adalah 20 orang dan siswa yang tidak tuntas 2 orang dengan persentase ketuntasan kelasikal 90,91\%.

Jadi, hasil evaluasi anatara siklus I dan siklus II yaitu pada siklus I ketuntasan kelasikal sebesar 63,64 \%. mengalami peningkatan pada siklus II yaitu $90.91 \%$. Sedangkan aktivitas siswa pada siklus pertama pertemuan pertama adalah 2,11 dan pada siklus pertama pertemuan kedua adalah 2,25 dan Aktivitas siswa pada siklus kedua pertemuan pertama adalah 2,89 dan pada siklus kedua pertemuan kedua adalah 3,0.

\section{Saran}

Adapun saran yang penulis dapat sampaikan sehubung dengan hasil penelitian ini adalah sebagai berikut: (1).Bagi siswa : Siswa di berikan kesempatan untuk belajar secara berkelompok dan dengan penerapan teori dienes siswa dapat meningkatkan prestasi belajar (2).Bagi guru : di harapkan agar dapat menggunakan dan mengoptimalkan teori dienes dalam mengajarkan materi apapun sehingga keaktivan siswa dalam melaksanakan pembelajaran lebih meningkat(3)Sekolah: di harapkan agar dapat memberikan himbauan kepada tenaga tenaga pengajar agar menggunakan teori dienes atau metode parmainan dalam pembelajaran yang dapat meningkatkan prestasi belajar siswa.

\section{DAFTAR PUSTAKA}

Aisyah Nymas, dkk., (2007: 2.7). Pengembangan Pembelajaran Matematika SD. Jakarta: Depdiknas

Anwar Syaiful, (1997:11). Latihan SPSS Statistik Parametrik. Jakarta: Elex Media

Arikunto, (2001: 62).“ Dasar-Dasar Evaluasi Pendidikan. Jakarta: Bumi Aksara.
Bloom (Cece Rakhmat, dkk., 2006 : 209) "Metodologi. Penelitian Sastra" Salatiga: P.T. Bumi Aksara Nurkancana

Hamalik Oemar,( 1983:11). (2001). Proses Belajar Mengajar. Jakarta : Bumi Aksara.

Karso (1999:1.20) Pendidikan Matematika I. Jakarta: Universitas Terbuka

Poerwadarminta WJS. (2006: 901) Kamus Umum Bahasa Indonesia. Jakarta : Balai. Pustaka

Raka joni (dalam Rakhmat, dkk., (2006 : 209)

Dalam buku kumpulan jurnal Pesantren dan Pembaharuan. Jakarta: LP3ES.

Saifuddin dkk, (2008:40). Sinopsis Obstetric Jilid I. EGC : Jakarta

Slameto. (2003 : 2) "Evaluasi Pendidikan. Salatiga: P.T. Bumi Aksara Nurkancana

Syaiful Bahri Djamarah, (1994:19), Psikologi Belajar, Jakarta : Rineka Cipta, 2008 . 